\title{
Synthesis, characterization and analytical applications of chelating resin containing orcinol
}

\author{
Bhavna A. Shah ${ }^{* 1}$, Ajay V. Shah', Nayan B. Patel ${ }^{1}$, Pathik M Shah ${ }^{3}$ \\ ${ }^{1}$ Veer Narmad South Gujarat University, Department of Chemistry, Surat, Gujarat, India. \\ ${ }^{2}$ Department of Chemistry, Polytechnic, Vidhyabharti Trust, Umrakh, Bardoli, Gujarat, India \\ ${ }^{3}$ Central Institute of Plastics Engineering \& Technology, Vatva, Ahmedabad. Gujarat. India. \\ *Corresponding author: e-mail: bhavna606@gmail.com
}

\begin{abstract}
A chelating resin based on Salicylic acid-Formaldehyde copolymer, containing Orcinol (SFO), has been synthesized and characterized on the basis of Elemental Analysis, Particle Size Distribution, FT-IR Analysis, XRD, SEM and Optical Photographs. The Physico-Chemical properties have been studied. This resin is highly stable in acidic and alkaline solutions and has been studied as a chelating sorbent for heavy metal ions and transition metal ions. The Exchange capacity order is $\mathrm{Ni}(\mathrm{II})>\mathrm{Cu}$ (II) $>$ $\mathrm{Zn}(\mathrm{II})>\mathrm{Cd}(\mathrm{II})>\mathrm{Pb}(\mathrm{II})$. The effect of nature and concentration of different electrolytes on distribution coefficient $\left(\mathrm{K}_{\mathrm{d}}\right)$ for metal ions have been investigated. Separation of synthetic mixtures containing $\mathrm{Cu}(\mathrm{II})-\mathrm{Pb}(\mathrm{II}), \mathrm{Ni}(\mathrm{II})-\mathrm{Cd}(\mathrm{II})$ and Brass constituents has been carried out using a column prepared from the synthesized chelating resin. The developed procedure was also tested for the removal of $\mathrm{Cd}(\mathrm{II})$ and $\mathrm{Pb}$ (II) from natural water of Purna River near by Navsari, Gujarat, India.
\end{abstract}

Keywords: Analytical Separation, Chelating Resin, Column Operation, Copolymer, Exchange Capacity.

\section{INTRODUCTION}

Water pollution is a major environmental problem faced by modern society that leads to ecological disequilibrium and health hazards ${ }^{1}$. Metal ions such as copper, cadmium, lead, nickel and chromium often found in industrial wastewater, exhibit acute toxicity to aquatic and terrestrial life, including humans. Thus, the discharge of effluents into the environment is a chief concern. Many separation techniques using solvent extraction and ion exchange chromatography have been applied for this purpose. Ion exchange is a popular method owing to its applicability to both preconcentration and separation ${ }^{2,3}$.

Park and $\mathrm{Kim}^{4}$ synthesized chelating resins containing carboxylic acid by suspension polymerization of styrene, methyl methacrylate and divinylbenzene in the presence of toluene. These resins were demonstrating good affinity for heavy metal ions like $\mathrm{Pb}(\mathrm{II}), \mathrm{Cd}(\mathrm{II})$ and $\mathrm{Hg}(\mathrm{II})$. A novel chelating copolymer resin was synthesized through the copolymerization of o-aminophenol and melamine with formaldehyde (o-APMF resin) ${ }^{5}$. This resin was useful for the separation and recovery of $\mathrm{Pb}$ (II) from synthetic binary mixtures of some metal ions. Singh and Srivastava ${ }^{6}$ prepared a chelating resin by condensing p-bromophenyl - hydroxamic acid, formaldehyde and salicylic acid and used this resin for the removal and recovery of $\mathrm{Cu}$ (II) and $\mathrm{Fe}$ (III) from synthetic seawater. The removal, separation and recovery of heavy metal ions from industrial wastewater have been a significant concern in all industrial branches owing to economic and environmental factors. Separation techniques such as ion exchange, solvent extraction, extraction chromatography, electodeposition, solid phase extraction and coprecipitation have been successfully used for the separation and preconcentration of several metal ions ${ }^{7,8}$.

The aim of this article is to study the ability of chelating resin that contains hydroxyl and carboxylic acid groups as active sites. The chelating resin was synthesized from salicylic acid, formaldehyde and orcinol (SFO). This resin was characterized by different instrumental technique.
The optimum condition for the efficient exchange of metal ions on synthesized resin was determined by varying contact time, $\mathrm{pH}$ and metal ion concentrations. The effect of salts like $\mathrm{NaCl}, \mathrm{Na}_{2} \mathrm{SO}_{4}, \mathrm{NaNO}_{3}$ and tartaric acid on distribution coefficient (Kd) was investigated. Using this resin, the quantitative separation of $\mathrm{Cu}(\mathrm{II})$ $\mathrm{Pb}$ (II) and $\mathrm{Ni}(\mathrm{II})-\mathrm{Cd}(\mathrm{II})$ were achieved on the columns of the chelating resin. The chelating resin has also been studied for the separation of $\mathrm{Cu}$ (II) and $\mathrm{Zn}$ (II) from Brass sample and recovery of $\mathrm{Pb}(\mathrm{II})$ and $\mathrm{Cd}(\mathrm{II})$ from Purna river water.

\section{EXPERIMENTAL METHODS}

\section{Reagents and Solutions}

Analytical reagent (A.R) grade chemicals were used unless otherwise stated. Stock solutions $(1 \mathrm{~g} / \mathrm{L})$ of metal ions were prepared by dissolving appropriate amounts of metal acetate in deionized water, acidified with 5 $\mathrm{mL}$ of the corresponding acid. The working solutions of metal ions were obtained by dilution of the stock solutions with double distilled water. The solutions were adjusted to various $\mathrm{pH}$ using acetate buffer. The water samples from the Purna River (Navsari, Gujarat, India) was collected, acidified with $2 \% \mathrm{HNO}_{3}$ immediately, filtered and stored in the glass bottles. The Solutions of hydrochloric acid, tartaric acid, acetic acid, sodium acetate and sodium hydroxide were prepared by dissolving appropriate amount of the particular compound in double distilled water. All solutions were standardized by the literature methods ${ }^{\mathbf{9}, 10}$.

\section{Instrumental Analysis}

A flame atomic absorption spectrophotometer (AAS) (Electronic Corporation of India Ltd, Hyderabad, India, Model 4129) with an air-acetylene flame (air and acetylene flow rates: $10 \mathrm{~L} / \mathrm{min}$ and $2.0 \mathrm{~L} / \mathrm{min}$, respectively) was used for analysis. The wavelength $(\mathrm{nm})$ used for the monitoring of $\mathrm{Ni}, \mathrm{Cu}, \mathrm{Zn}, \mathrm{Cd}$ and $\mathrm{Pb}$ are 232.0, 
324.8, 213.9, 228.8 and 217.0 respectively. The particle size of the synthesized resin (SFO) was measured by the "Malvern particle size analyzer" (Mastersizer-2000). The elemental analysis was carried out on the "Elemental Analyser" (Carlo Erba, model 1160). The FT-IR Spectra of the synthesized resin sample had been scanned in the $\mathrm{KBr}$ pallets on "FTIR Spectrophotometer" (Shimadzu model-8201PC). The X-Ray Diffraction Analysis (XRD) was performed by the advanced "Diffractometer" (Bruker AXE D8). The surface analysis was done using an optical photograph (Olympus SZX12) and a scanning electron microscope (Philips XL30) at different magnifications. A mechanical shaker equipped (speed of 200 strokes min-1) with an incubator (Hindustan Scientific, New Delhi, India) was used for the equilibration of metal ions with chelating resin.

\section{Resin Synthesis}

The recrystallised salicylic acid $(0.1$ mole, $13.7 \mathrm{~g})$ was ground to a fine powder and dissolved in $30 \mathrm{~mL}$ DMF solvent to give a clear solution. It was taken in a 250 $\mathrm{mL}$ three necked round bottom flask which was fitted with a condenser, a thermometer, and an addition funnel. Formaldehyde (37\% w/v, 0.3 mole) was added to the above solution from the addition funnel dropwise with constant stirring. A solution of orcinol ( 0.1 mole, $12.4 \mathrm{~g}$ ) in $20 \mathrm{~mL}$ of DMF was added to the above solution dropwise at the flow rate of $2 \mathrm{~mL} / \mathrm{min}$ from the addition funnel at room temperature and stirred for 1 hour. The mixture was refluxed on a water bath with constant stirring at $80 \pm 2^{\circ} \mathrm{C}$ for $45-60$ minute until a viscous solution was obtained with the formation of a jelly mass of dark brown color resin.

This jelly mass then dried in open to soft solid mass. It was ground to small pieces. The resin was cured in an oven at $70-75^{\circ} \mathrm{C}$ for 12 hour. The resin particles were washed with DMF and ethanol and finally with hot distilled water till the complete removal of monomer impurities was achieved ${ }^{\mathbf{1 1}}$. After a complete washing cycle, the yield of this resin was found to be 70-80\% (18-20 g). The solubility tests of the resin were performed at room temperature with intermittent shaking. It was found insoluble in all common organic solvents like acetone, ethanol, benzene, DMF, DMSO, $\mathrm{CCl}_{4}$, chloroform etc. and all acids and alkalies of higher strengths. As carboxylic acid groups normally get decomposed above $100^{\circ} \mathrm{C}$. The resin was cured below $90^{\circ} \mathrm{C}$.

The purified and dried resin sample (SFO) was finely ground and sieved to the obtained uniform particle of 20-50 mesh size and stored in a polyethylene bottle. The sieved resin sample was analyzed for particle size distribution. The structural and surface morphology of dry resin samples were examined by elemental analysis, FTIR spectra, XRD analysis, optical photograph and SEM analysis. The probable unit structure and the reaction scheme are given in Scheme 1.

The resin sample having uniform particle size $(20-50$ mesh) was equilibrated with $2 \mathrm{M}$ HCI solution for 24 hours to convert it in $\mathrm{H}^{+}$form and washed with deionized water till it was freed from chloride by testing with silver nitrate solution. The $\mathrm{H}^{+}$form of resin was used for further studies. It is necessary to evaluate ion exchange processes in terms of resin properties such
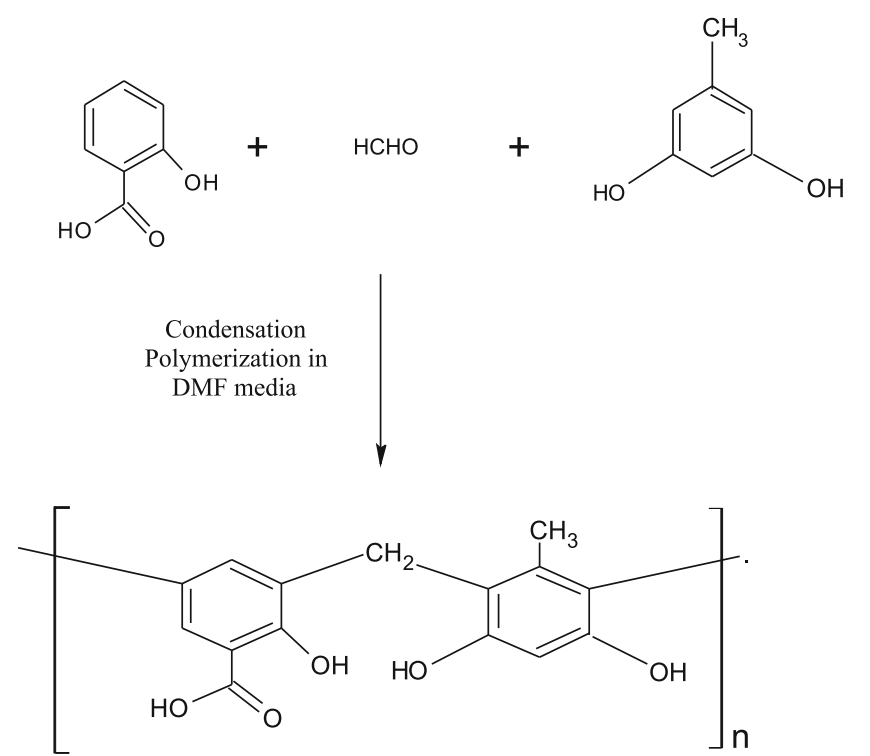

Scheme 1. Reaction Scheme for synthesized resin

as $\%$ moisture content, void volume fraction, exchange capacity for sodium ion and other heavy metal ions ${ }^{9,10}$.

\section{Effect of Contact Time on Exchange Capacity}

To study the effect of important parameters like contact time, $\mathrm{pH}$, metal ion concentration and temperature, batch equilibration method has been adopted at room temperature $\left(30 \pm 2^{\circ} \mathrm{C}\right)$. To study the effect of contact time on the exchange of metal ions, $\mathrm{H}^{+}$form of accurately weighed $(0.250 \pm 0.001 \mathrm{~g})$ dry resin sample was taken in different glass stopper bottles and equilibrated with buffer solutions of optimum $\mathrm{pH}$ value ( $\mathrm{pH}$ of which highest ion exchange capacity is observed) for $6 \mathrm{~h}$. After decanting buffer solution, $50 \mathrm{~mL}(500 \mathrm{ppm})$ metal ion solutions of the same $\mathrm{pH}$ was added. The amounts of residual metal ions were determined by Atomic Absorption Spectroscopy at fixed time intervals. The exchange capacity was determined by the following equation:

$q_{e}=\frac{(\mathrm{Co}-\mathrm{Ce}) \mathrm{V}}{W}$

Where $\mathrm{Co}$ and $\mathrm{Ce}$ are the initial and equilibrium concentration of metal ions in the aqueous phase respectively and $\mathrm{V}$ is volume of metal ion solution in $\mathrm{mL}$ and $\mathrm{W}$ is weight of resin in gram.

\section{Effect of pH on Exchange Capacity}

To study the effect of $\mathrm{pH}$ on the metal ion uptake, it is necessary to buffer the resin and then the solutions were used. Different sets of accurately weighed $(0.250 \pm 0.001$ g) dry resin having uniform particle size (20-50 mesh) were equilibrated with buffer in different glass stopper bottles for $6 \mathrm{~h}$, so that resin attained desired $\mathrm{pH}$ value. After $6 \mathrm{~h}$, buffer solutions were decanted and $50 \mathrm{~mL}$ of $500 \mathrm{ppm}$ metal ion solutions of varying $\mathrm{pH}$ from 3-7 were added. Metal ion solutions were equilibrated at room temperature $\left(30 \pm 2^{\circ} \mathrm{C}\right)$ for $24 \mathrm{~h}$ with intermittent shaking. After $24 \mathrm{~h}$, the solutions were filtered with 0.02 $\mu \mathrm{m}$ membrane filter to separate the resin and solution. The $\mathrm{pH}$ of the filtrate was measured and it was found that $\mathrm{pH}$ remains stable throughout the experiment $( \pm 0.2)$. From the filtrate the unchelate metal ions were estimated by atomic absorption spectroscopy. 


\section{Effect of Metal Ion Concentration on Exchange Capacity}

To study the effect of metal ion concentration by the synthesized resin, the accurately weighed $(0.250 \pm 0.001 \mathrm{~g})$ dry resin was equilibrated with acetate buffer at desired $\mathrm{pH}$ values ( $\mathrm{pH}$ value of highest exchange) for $6 \mathrm{~h}$ and then buffer solutions were decanted and metal ion solutions $(50 \mathrm{~mL})$ of varying molar concentration i.e. $100-500$ ppm of the same $\mathrm{pH}$ value were added and equilibrated at room temperature for $24 \mathrm{~h}$ with intermittent shaking. After $24 \mathrm{~h}$ metal ion solutions were filtered and the unchelate metal ions were estimated.

\section{Effect of Temperature on Exchange Capacity}

To study the effect of temperature equilibration experiments were performed at fixed metal ion $[\mathrm{Cu}(\mathrm{II})]$ concentration $(300 \mathrm{ppm})$ for fixed resin loading $(0.250 \pm 0.001$ g) and optimum $\mathrm{pH}$ at four different temperatures i.e. $30,40,50$ and $60^{\circ} \mathrm{C}$ for $8 \mathrm{~h}$.

\section{Effect of Different Electrolytes Concentration on Distri- bution Coefficient (Kd) of Metal Ions}

The dry resin sample $(0.250 \pm 0.001 \mathrm{~g})$ was suspended in the different electrolyte solution like tartaric acid, $\mathrm{NaCl}, \mathrm{NaNO}_{3}$ and $\mathrm{Na}_{2} \mathrm{SO}_{4}(50 \mathrm{~mL})$ of different known concentrations. The $\mathrm{pH}$ of the suspension was adjusted to the desired value and the resin was equilibrated for $6 \mathrm{~h}$. To the suspension, $2.0 \mathrm{~mL}$ of $(5.0 \mathrm{mg} / \mathrm{mL})$ solution of the metal ion under study was added. The $\mathrm{pH}$ was again adjusted to a desired value. The mixture was further equilibrated for 24 hours and then filtered. The solid was washed with water. The filtrate and washings were combined and examined for the metal ion concentration. $K_{d}=\frac{\{\mathrm{Wt} \text {. (in } \mathrm{mg} \text { ) of metal ions taken up by } 1 \mathrm{~g} \text { of resin }\}}{\{\mathrm{Wt} \text {. (in } \mathrm{mg} \text { ) of metal ions present in } 1 \mathrm{~mL} \text { of resin }\}}$

\section{Analytical Column Separations}

The chelating resin in $\mathrm{H}^{+}$form was equilibrated at the desired $\mathrm{pH}$ and packed into a chromatographic column to form a bed $17 \mathrm{~cm}$ height and $0.4 \mathrm{~cm}$ diameter. Mixtures of metal ions (10 $\mathrm{mg}$ of each per $20 \mathrm{~mL}$ ) at appropriate $\mathrm{pH}$ were passed through the column at a flow rate of $0.5 \mathrm{~mL} / \mathrm{min}$. The chelated metal ions were eluted using tartaric acid. During the elution, a flow rate of $0.5 \mathrm{~mL} /$ min was maintained.

\section{Separation of Metal ions from Brass Sample}

Brass is an alloy containing $60 \% \mathrm{Cu}$ and $40 \% \mathrm{Zn}$. Brass sample $(0.250 \pm 0.001 \mathrm{~g})$ was dissolved in about $10.0 \mathrm{~mL}$ of concentrated nitric acid and the solution was evaporated to dryness. The residue was dissolved in $10.0 \mathrm{~mL}$ of $0.1 \mathrm{M}$ hydrochloric acid. The solution was filtered and made it up to $25.0 \mathrm{~mL}$ by addition of distilled water in standard measuring flask. From this, $5.0 \mathrm{~mL}$ of the solution was taken for column separation. This aliquot was directly passed through the column of the synthesized resin at a flow rate of $0.5 \mathrm{~mL} / \mathrm{min}$.

\section{Recovery of Heavy Metal Ions from Purna River Water}

20 liter of Purna River water sample from Navsari city was collected in a polythene container. Several water samples were analyzed to contain $\mathrm{Cd}(\mathrm{II})$ (0.01 to 0.17 ppm) and $\mathrm{Pb}$ (II) (0.01 to $0.4 \mathrm{ppm}$ ), which is higher than the Indian Standard Desirable Limits. It exhibits higher concentration of these metal ions at Jalalpor and Weircum Causeway. This may be due to industrial effluent of sewage waste in the river water. One liter of water sample was recycled through the resin columns for the preconcentration of these metal ions at a flow rate of $1 \mathrm{~mL} / \mathrm{min}$. The elution was performed at optimized condition based on $\mathrm{K}_{\mathrm{d}}$ values.

\section{RESULT AND DISCUSSION}

\section{Instrumental Analysis}

The particle size distribution curve is shown in Figure 1. The particle size for resin is quite homogeneous. The average particle size of resin is found to be in the range of 250-850 micrometer (20-50 mesh). It provides the optimum size for the exchange of the ions and also comparable with the commercial resins.

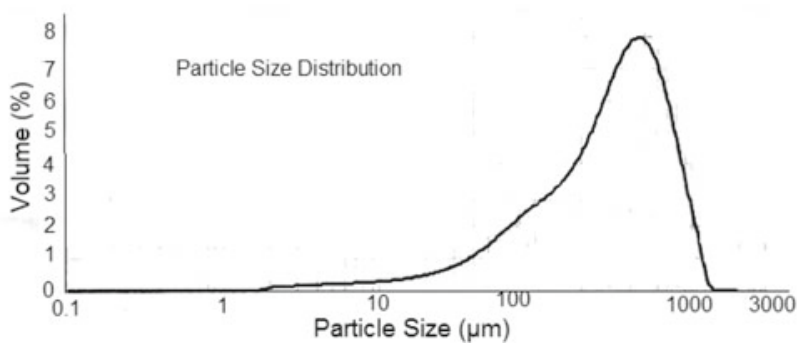

Figure 1. Particle size distribution curve of SFO resin

The $\% \mathrm{C}, \% \mathrm{H}$ and $\% \mathrm{~N}$ was calculated by from the general formula $\left(\mathrm{C}_{15} \mathrm{H}_{12} \mathrm{O}_{5}\right)$ of the repeating unit of the assumed structure (Scheme 1) of the synthesized resin. The result of the elemental analysis is in good agreement with calculated values of $\mathrm{C}, \mathrm{H}$ and $\mathrm{N}$, which is shown in Table 1. The values of Elemental Analysis confirm the proposed structures of the resin presented in Scheme 1.

Table 1. Elemental analysis and Physico-chemical properties of SFO resin

\begin{tabular}{|l|c|}
\hline Properties & Value \\
\hline$\%$ C Calculated (Found) & $66.17(66.53)$ \\
\hline$\%$ Calculated (Found) & $4.41(4.79)$ \\
\hline$\%$ Moisture & 3.11 \\
\hline$\%$ Solid & 96.89 \\
\hline True density $\left(\mathrm{d}_{\mathrm{res}}\right)\left(\mathrm{g} / \mathrm{cm}^{3}\right)$ & 1.111 \\
\hline Apparent density $\left(\mathrm{d}_{\mathrm{col}}\right)(\mathrm{g} / \mathrm{ml})$ & 0.740 \\
\hline Void volume fraction & 0.333 \\
\hline $\begin{array}{l}\text { Sodium Exchange Capacity }(\mathrm{mmol} / \mathrm{g} \text { dry } \\
\text { resin) }\end{array}$ & 4.948 \\
\hline $\begin{array}{l}\text { Concentration of fixed ionogenic group } \\
\left(\mathrm{mmol} / \mathrm{cm}^{3}\right)\end{array}$ & 5.260 \\
\hline Volume capacity $\left(\mathrm{mmol} / \mathrm{cm}^{3}\right)$ & 3.508 \\
\hline
\end{tabular}

The strong band at $3414.36 \mathrm{~cm}^{-1}$ for resin is due to the $v(\mathrm{O}-\mathrm{H})$ stretching of phenolic group. The presence of the medium band at $2942.87 \mathrm{~cm}^{-1}$ for resin is due to the $v(\mathrm{C}-\mathrm{H})$ stretching of methylene group ${ }^{\mathbf{1 2}}$. The medium strong band at $1652.81 \mathrm{~cm}^{-1}$ for resin can be assigned to $v(\mathrm{C}=\mathrm{O})$ stretching of aromatic acid group. The medium band at $1099.38 \mathrm{~cm}^{-1}$ for resin which is due to the $\delta(\mathrm{C}-\mathrm{H})$ bending of 1, 2, 3, 5-tetra substituted benzene ring. The medium band at $1466.52 \mathrm{~cm}^{-1}, 760.15 \mathrm{~cm}^{-1}, 1376.12 \mathrm{~cm}^{-1}$ for resin is due to the $\delta(\mathrm{C}-\mathrm{H})$ bending, $\delta(\mathrm{C}-\mathrm{H})$ rocking, $\delta(\mathrm{C}-\mathrm{H})$ wagging of ethylene $\left(-\mathrm{CH}_{2}-\right)$ bridges, which can be observed in Figure 2. 


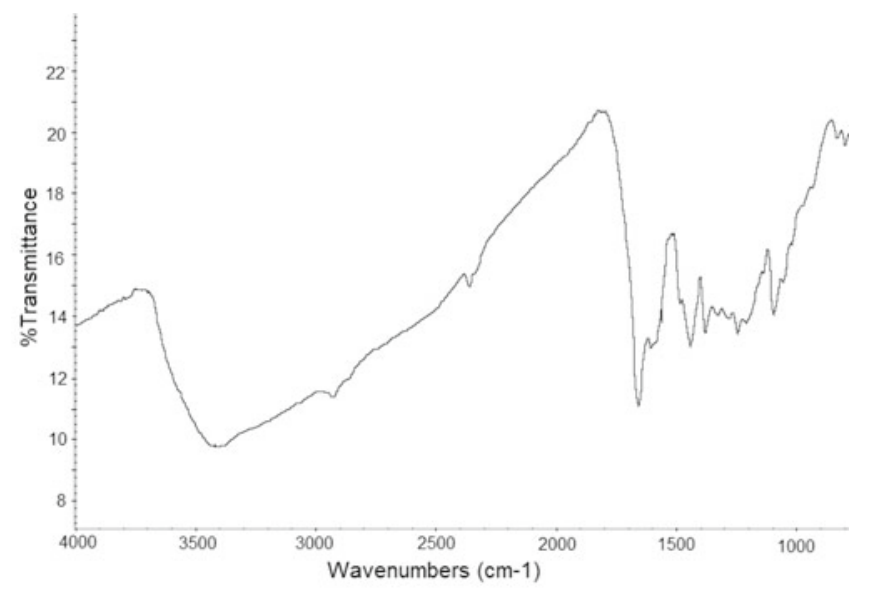

Figure 2. FTIR spectra of SFO resin

The XRD patterns of the compound provide the information about the crystalline or amorphous nature of the compound or crystalline and amorphous regions that may co-exist in the same compound $d^{13,14}$. The XRD pattern of resin is shown in Figure 3. Some very few sharp peaks are observed in the difractograms of resin. The resin exhibits characteristic of the low percentage of crystalline nature with an amorphous phase.

Surface analysis has found great use in the understanding of the surface features of the material. The morphology of the synthesized resin sample was investigated by scanning electron micrographs and optical photographs. The SEM photographs are shown in Figure 4 at (a) 200X and (b) 1000X magnifications and optical photographs are shown in Figure 5 (140X-220X). The white bar at the bottom of the SEM micrographs represents the scale. SEM and optical photographs of SFO resin sample was taken to characterize particle shape, size and surface morphology. From the SEM photographs, (Figure 4) it is observed that resin exhibits angular edges with regular fringes. The morphology of the resin shows a fringed micelle model of the crystalline structure. The fringes represent the transition material between crystalline and amorphous phases. The SEM photographs of resin exhibits such spherulites, which are the aggregate of crystallites present in the amorphous regions. SFO resin has more amorphous region as compare to $o$-APMF $\operatorname{resin}^{5}$. The synthesized resin is more compact and rigid. Optical photographs (Figure 5) of the synthesized resin exhibit that the resin is dark brown in color.

\section{Physico-Chemical Properties}

The physico-chemical properties of the synthesized resin are presented in Table 1. The percentage of moisture content of the synthesized resin is 3.11. It has been observed that this resin has low range of percentage moisture content compared to the commercial resins. The amount of cross linking in the bead has an impact on the moisture content of the bead and the moisture content in turn has an impact on the selectivity. A bead with high moisture content has a high porosity and the active groups are spaced further apart from each other. The resin synthesized from salicylic-formaldehyderesorcinol $^{15}$ and salicylic acid-formaldehyde- m-cresol ${ }^{16}$ exhibited higher moisture content than the synthesized resin (SFO). The difference in the moisture content may be due to the different experimental conditions such as the medium in which the resins are synthesized, polymeric

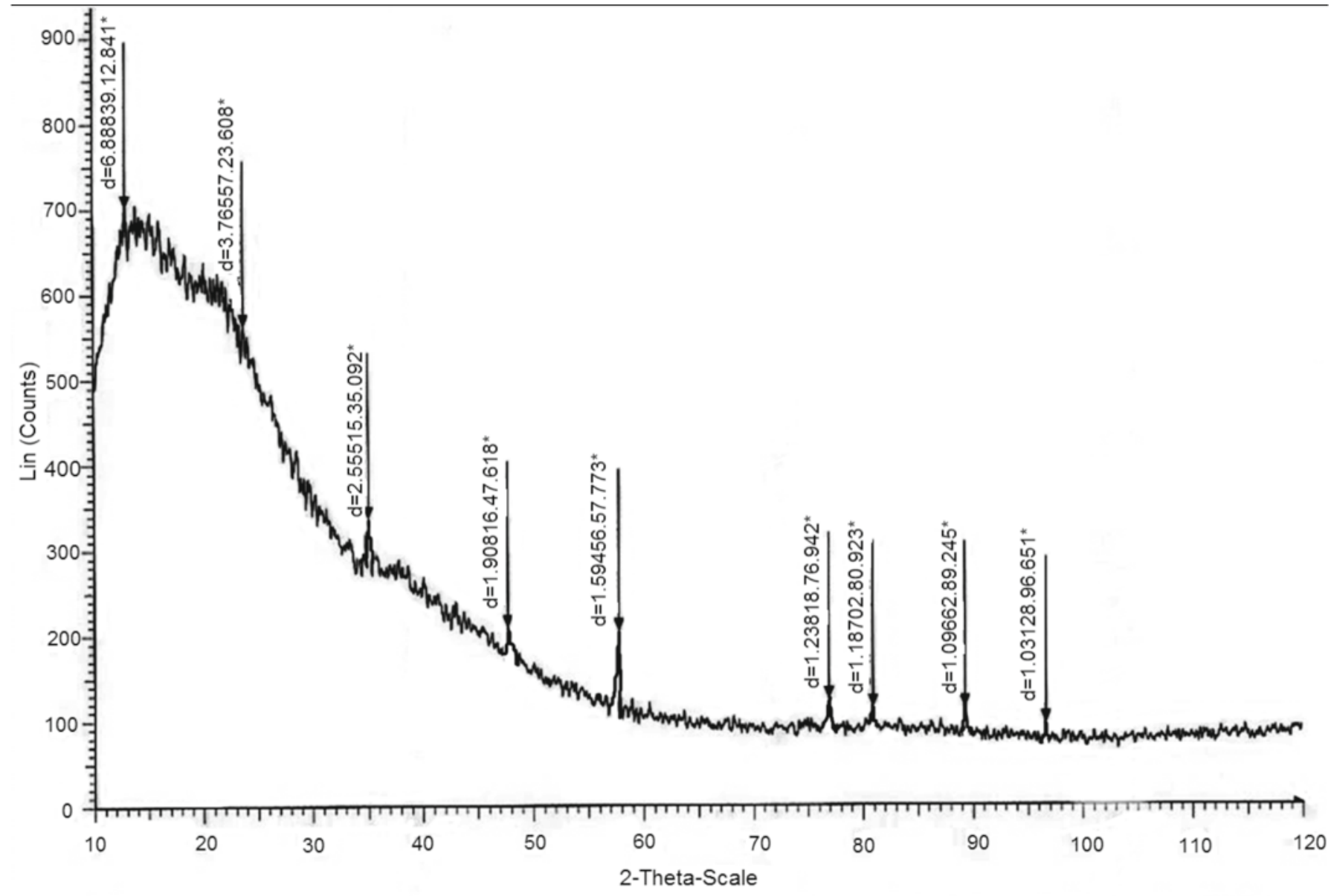

Figure 3. XRD pattern of SFO resin 

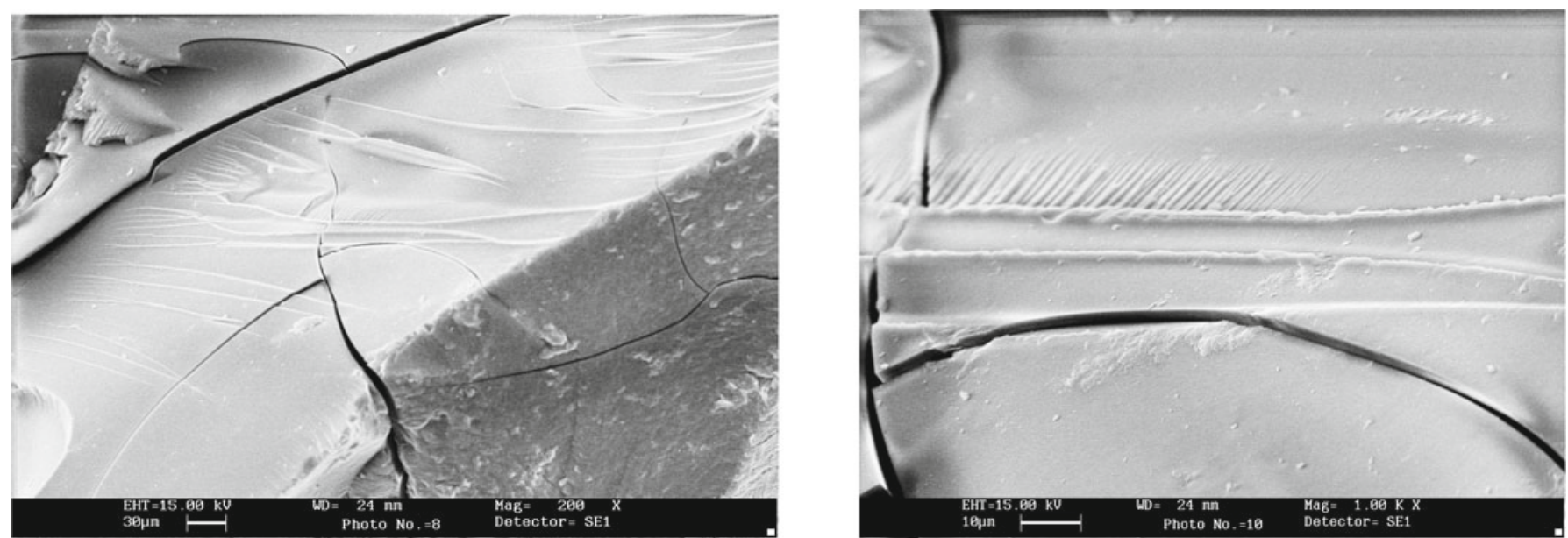

[a]

Figure 4. SEM photographs of SFO resin at [a] 200X and [b] 1000X magnification
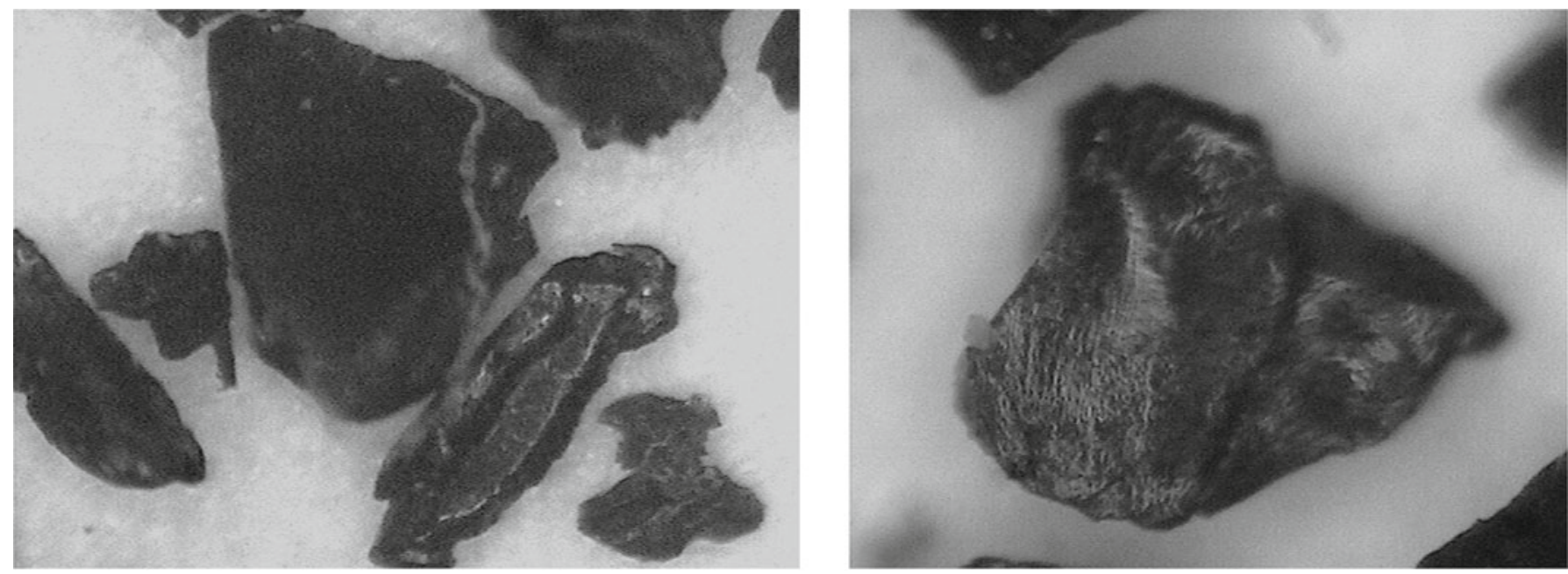

[a]

[b]

Figure 5. Optical photographs of SFO resin at [a] 140X and [b] 220X magnification

backbones and functional groups involved.

The true density of the synthesized polymer is shown in Table 1 which is $1.11 \mathrm{~g} / \mathrm{cm}^{3}$. The true density of commercial resins generally lies between $1.1 \mathrm{~g} / \mathrm{cm}^{3}$ to $1.7 \mathrm{~g} / \mathrm{cm}^{3}$. To avoid the floating of resin particles, true density must be more than one. The apparent density of the synthesized resin is 0.740 which is given in Table 1 , which is comparable to the density of commercial resins. It may be because of charge in polymeric matrix, different functional group and the method of synthesis. The apparent density parameter gives an idea of probable length of the packed column for an ideal column chromatography study. The value of void volume fraction of resin is 0.333 which is represented in Table 1 . The appreciable values of void volume fraction help the diffusion of the exchangeable ion on the resin and hence increase the rate of the exchange of ions.

\section{Effect of Contact Time on Exchange Capacity}

The exchange of metal ions on resin exhibits the time dependent phenomenon. The rate of exchange for different metal ions is illustrated in Figure 6. The graph shows that the time required for $50 \%$ exchange $\left(t_{1 / 2}\right)$ of $\mathrm{Ni}(\mathrm{II}), \mathrm{Cu}$ (II) and $\mathrm{Zn}$ (II) is $30 \mathrm{~min}$., for $\mathrm{Cd}(\mathrm{II})$ is $40 \mathrm{~min}$. and for $\mathrm{Pb}(\mathrm{II})$ is $50 \mathrm{~min}$. The faster rate of exchange in the beginning can be explained on the basis of the law of mass action ${ }^{17}$. The faster rate of exchange facilitates column chromatographic separation. The kinetics of metal ion exchange mainly depends on the various physical properties like particle size distribution, pore size, physical core structure and diffusion of counter ion. The time required for $100 \%$ uptake of metal ions was $21 \mathrm{hr}$.

\section{Effect of pH on Exchange Capacity}

The polymer surface chemistry as well as the solution chemistry of these metal ions is $\mathrm{pH}$ dependent. Changes in $\mathrm{pH}$ are known to affect the adsorbent's surface charge and the adsorbate's degree of ionization and speciation ${ }^{18}$. The result is presented as the exchange capacity against $\mathrm{pH}$ for the metal ions in Figure 7. The maximum exchange for $\mathrm{Ni}(\mathrm{II})$ and $\mathrm{Cu}(\mathrm{II})$ take place at $\mathrm{pH} 6.0$ and for $\mathrm{Zn}(\mathrm{II}), \mathrm{Cd}(\mathrm{II})$ and $\mathrm{Pb}$ (II) at $\mathrm{pH}$ 5.0. The results show that the exchange of metal ions was increased with the increase in $\mathrm{pH}$ up to a certain value and thereafter it decreased. An increase in $\mathrm{pH}$ increases the negatively charged nature of the sorbent surface. This leads to an increase in the electrostatic attraction between the positively charged metal ions and the negatively charged sorbent and results in the increase in the uptake of metal ions. The decrease in the removal of metal ions at lower $\mathrm{pH}$ is due to the higher concentration of $\mathrm{H}^{+}$ions present in the reaction mixture which 


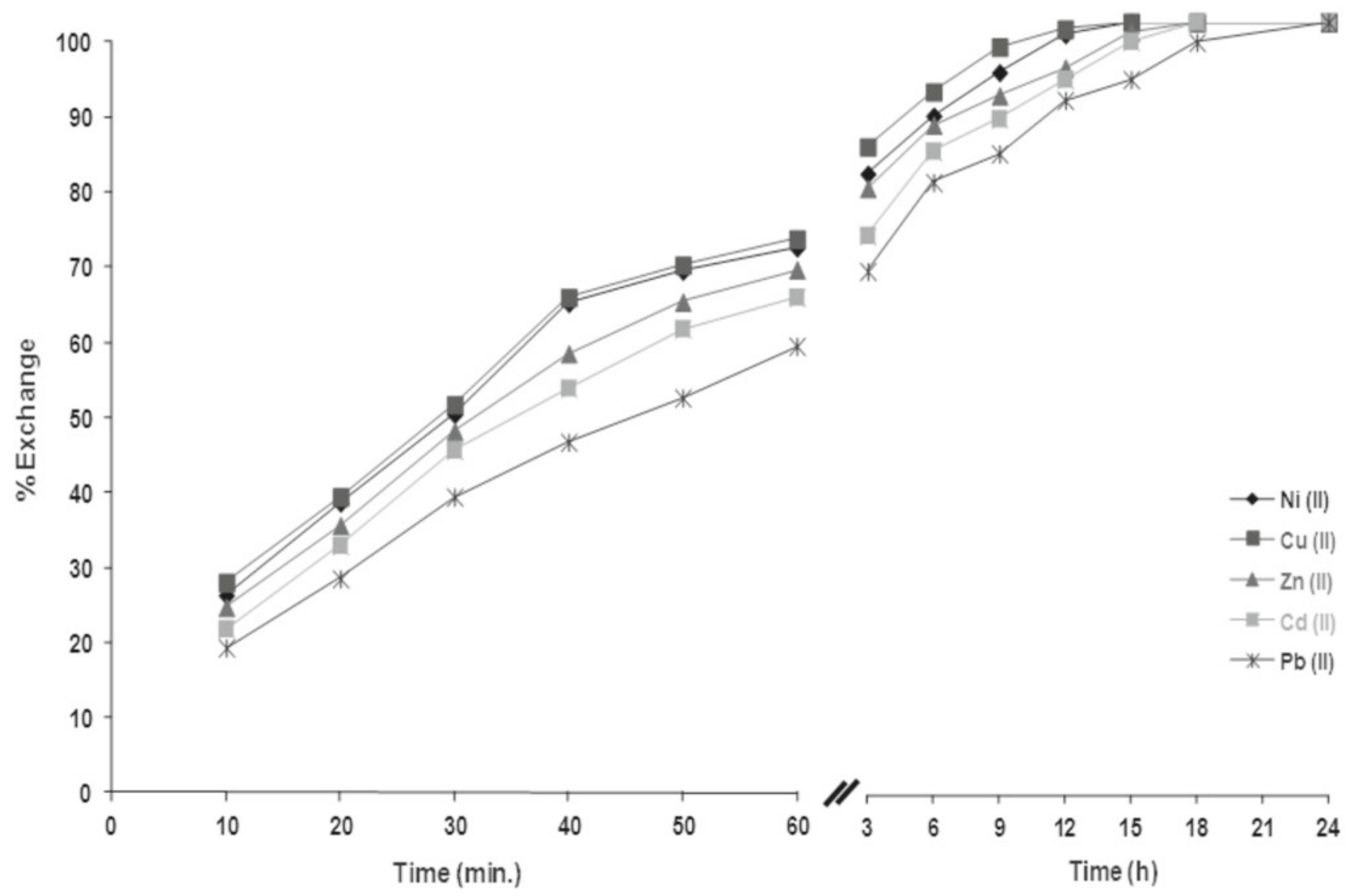

Figure 6. The effect of $\mathrm{pH}$ on metal ion exchange capacity on SFO resin

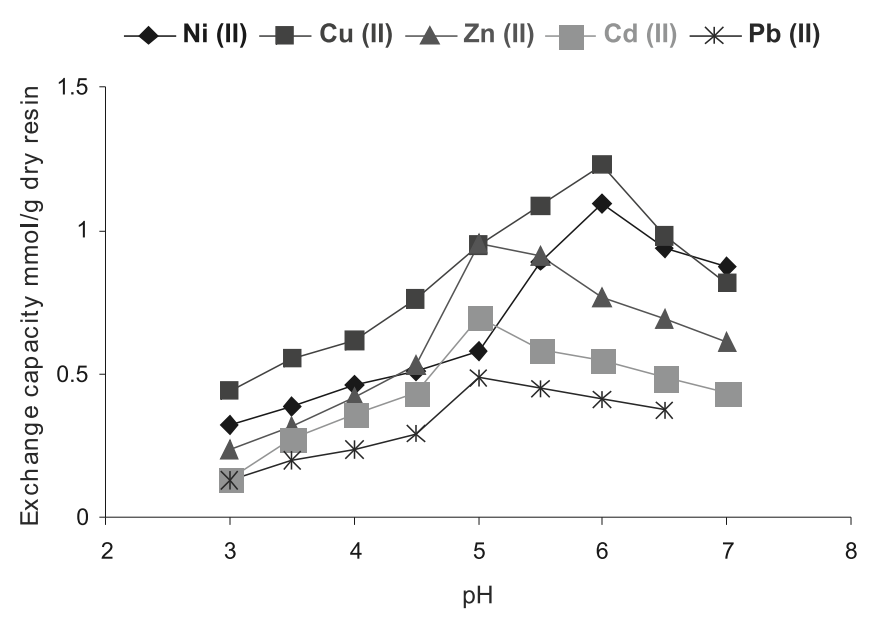

Figure 7. The rate of exchange for metal ion exchange capacity on SFO resin

compete with the metal ions for the exchange sites on the sorbent surface. Meanwhile the observed decrease in the exchange at higher $\mathrm{pH}$ is due to the formation of insoluble hydroxide of the metal ions ${ }^{\mathbf{1 9 , 2 0}}$. From the nature of the trend observed it is indicated that the cation exchange behavior of this resin is similar to acidic cation exchangers, ${ }^{4,19}$.

The selectivity order for metal ions is $\mathrm{Cu}(\mathrm{II})>\mathrm{Ni}(\mathrm{II})$ $>\mathrm{Zn}(\mathrm{II})>\mathrm{Cd}(\mathrm{II})>\mathrm{Pb}(\mathrm{II})$. The resin shows low exchange capacity for heavy metal ions as compared to other metal ions under study. The exchange capacity of $\mathrm{Zn}(\mathrm{II})$ is also found less as compared to other transition metal ions of $3 \mathrm{~d}$ series. This can be explained on the basis of $\Pi$ bonding electrons. It is observed that metal chelate forming capacity for $3 \mathrm{~d}$ series metal ions goes on decreasing from $\mathrm{Cu}(\mathrm{II})>\mathrm{Ni}(\mathrm{II})>\mathrm{Zn}(\mathrm{II})$, due to the less availability of $\Pi$ bonding electrons. The lower capacity of $\mathrm{Zn}(\mathrm{II})$ can also be explained by greater hydrated-ion radius of $\mathrm{Zn}(\mathrm{II})$ than that of $\mathrm{Ni}(\mathrm{II})$ and $\mathrm{Cu}(\mathrm{II})$ which leads to lower stability. The transition elements $\mathrm{Cd}(\mathrm{II})$ and $\mathrm{Pb}(\mathrm{II})$ of $4 \mathrm{~d}$ series metal ions show less capacity. It is because of having greater hydrated ion radius than $3 \mathrm{~d}$ series transition metal ions under study. This will results in electrostatic attraction between the metal and coordinating group, lower the complex stability and hence lower the capacity. The ion exchange capacity is also influenced by the morphology of resin, which in turn, is related to the different groups present in monomers.

\section{Effect of Metal Ion Concentration on Exchange Capacity}

The examination of the data presented in Figure 8 reveals that the amount of metal ion uptake increases with the increase in the concentration of metal ions in solution until a maximum value, and will remain constant

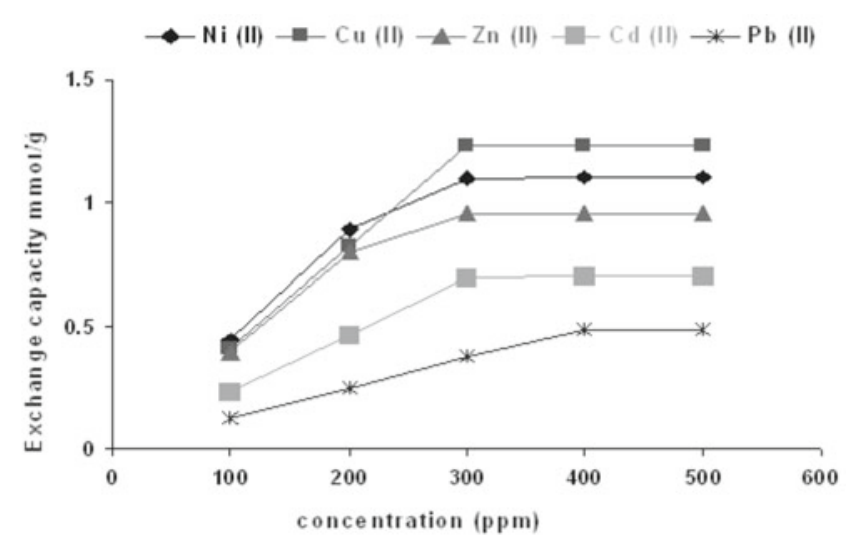

Figure 8. The efect of concentration on metal ion exchange capacity on SFO resin 
upon further increase in metal ion concentration. At a lower concentration of metal ions, the number of metal ions available in the solution is less as compared to the available sites on the sorbent. However, at higher concentration the available sites of exchange remain same, whereas more metal ions are available for the exchange and subsequently the exchange becomes almost constant then after. For $\mathrm{Ni}(\mathrm{II}), \mathrm{Cu}(\mathrm{II}), \mathrm{Zn}(\mathrm{II})$ and $\mathrm{Cd}(\mathrm{II})$ after $300 \mathrm{ppm}$ concentration ion exchange attains limiting value. For $\mathrm{Pb}(\mathrm{II})$ after $400 \mathrm{ppm}$ concentration metal ion uptake becomes constant.

\section{Effect of Temperature on Exchange Capacity}

Thermal stability test gives significant information for cation exchange capacity of resin. When resin was heated for $30^{\circ} \mathrm{C}$ to $60^{\circ} \mathrm{C}$ for $8 \mathrm{~h}$, it is observed that the $\mathrm{Cu}(\mathrm{II})$ exchange capacity remains unaltered. This may be due to cross linking between monomers, which produces tough resin. Resin shows little increase in the capacity at higher temperature. This is due to (1) the destruction of some $-\mathrm{CH}_{2}$ - bridge between aromatic ring, and (2) removal of decomposed products had neutralized the ionogenic groups. The thermal stability of resin makes resin useful for ion exchange chromatography at high temperature.

\section{Effect of Different Electrolytes Concentration on Distri- bution Coefficient $\left(K_{d}\right)$ of Metal Ions}

The distribution coefficient (Kd) of metal ions is function of concentration of different electrolyte solution. During the exchange of metal ions in the presence of electrolyte solution the difference in the distribution coefficient values is caused by the competition between metal ions and counter ions from electrolyte solution for the available exchange sites. To study the effect of electrolyte concentration on distribution coefficients of $\mathrm{Ni}(\mathrm{II}), \mathrm{Cu}(\mathrm{II}), \mathrm{Zn}$ (II), $\mathrm{Cd}(\mathrm{II})$ and $\mathrm{Pb}$ (II) ion, 0.05 to $1.0 \mathrm{M}$ solutions of tartaric acid, sodium chloride, sodium nitrate and sodium sulphate were used. The result is given in Table 2. It is observed that the metal ion distribution coefficients go on increasing as the concentration of electrolyte decreases. It was observed that there is a pronounced difference in the distribution coefficient values of sodium chloride, sodium nitrite and sodium sulphate.

The exclusion of the electrolyte solution from the resin goes on increasing with decreasing electrolyte concentration and hence increase in the distribution coefficient is observed. The electrolyte exclusion is more efficient with counter ions of low valency and co-ions of high valency. Therefore in the table, it is observed that the distribution coefficients, of the metal ions in presence of sodium sulfate have higher values than those in the presence of sodium chloride and sodium nitrate and the lower $\mathrm{K}_{\mathrm{d}}$ values observed in tartaric acid electrolyte, this may be due to the fact that the chelating group is available in tartaric acid.

The synthesized resin exhibits higher $\mathrm{K}_{d}$ values for $\mathrm{Cu}$ (II) and lower values for $\mathrm{Pb}(\mathrm{II})$. This may be explained on the basis of stability constant or the difference in the energy of the complexes according to Irving and Williams ${ }^{8}$. The value of the distribution ratio for the given concentration of electrolytes at optimum $\mathrm{pH}$ depends upon the nature and the stability of a chelate formation for particular metal ion. To achieve more clean separation of heavy metal ions in short time with practical elution volume, maximum $\left(\mathrm{K}_{\mathrm{d}}\right)$ value difference was selected for optimized conditions of chromatography.

Table 2. $\mathrm{K}_{\mathrm{d}}$ values of metal ions on SFO resin in different electrolyte at optimum $\mathrm{pH}$

\begin{tabular}{|c|c|c|c|c|c|}
\hline \multirow{2}{*}{ Metal ion } & \multirow{2}{*}{$\begin{array}{l}\text { Concentration of } \\
\text { electrolyte (M) }\end{array}$} & \multicolumn{4}{|c|}{$\mathrm{K}_{\mathrm{d}}$ values of electrolyte at optimum $\mathrm{pH}$} \\
\hline & & Tartaric acid & Sodium Chloride & Sodium Nitrite & Sodium Sulfate \\
\hline \multirow{4}{*}{$\mathrm{Ni}(I I)$} & 1.0 & 41.87 & 108.65 & 159.10 & 196.62 \\
\hline & 0.5 & 77.09 & 142.58 & 188.70 & 232.49 \\
\hline & 0.1 & 164.28 & 212.58 & 304.20 & 356.19 \\
\hline & 0.05 & 189.70 & 252.38 & 342.10 & 378.21 \\
\hline \multirow{4}{*}{$\mathrm{Cu}(\mathrm{II})$} & 1.0 & 95.71 & 148.28 & 222.10 & 261.80 \\
\hline & 0.5 & 138.31 & 176.91 & 259.42 & 284.18 \\
\hline & 0.1 & 208.65 & 221.05 & 271.70 & 304.58 \\
\hline & 0.05 & 312.89 & 288.42 & 376.17 & 438.61 \\
\hline \multirow{4}{*}{$\mathrm{Zn}(\mathrm{II})$} & 1.0 & 32.48 & 128.60 & 158.90 & 189.72 \\
\hline & 0.5 & 80.04 & 152.91 & 174.88 & 199.10 \\
\hline & 0.1 & 112.84 & 178.50 & 181.82 & 211.40 \\
\hline & 0.05 & 149.50 & 184.38 & 204.90 & 242.67 \\
\hline \multirow{4}{*}{$\mathrm{Cd}(\mathrm{II})$} & 1.0 & 23.61 & 78.43 & 108.50 & 132.47 \\
\hline & 0.5 & 49.12 & 87.58 & 122.70 & 155.10 \\
\hline & 0.1 & 91.47 & 112.91 & 142.88 & 194.33 \\
\hline & 0.05 & 109.24 & 138.04 & 177.60 & 223.10 \\
\hline \multirow{4}{*}{$\mathrm{Pb}(\mathrm{II})$} & 1.0 & 12.91 & 36.64 & 75.28 & 87.56 \\
\hline & 0.5 & 29.06 & 58.25 & 92.70 & 103.83 \\
\hline & 0.1 & 38.45 & 71.12 & 101.40 & 113.75 \\
\hline & 0.05 & 47.84 & 88.41 & 118.70 & 126.78 \\
\hline
\end{tabular}




\section{Analytical Column Separations}

The superior selectivity towards multivalent cations exhibited by chelating resin has been demonstrated in column experiments by using $\mathrm{K}_{\mathrm{d}}$ value. The values of the $\mathrm{K}_{\mathrm{d}}$ are shown in Table 2. An ideal situation would be such that one $K_{d}$ value is ten times greater than the $K_{d}$ value for the other ion, while the other approaches zero. The first eluting fraction of tartaric acid carries one metal ion, which has a smaller $\mathrm{K}_{\mathrm{d}}$ value. The second metal ion can be eluted by changing the tartaric acid concentration to a level that has a lowest $\mathrm{K}_{\mathrm{d}}$ value for second metal ion. The separation of $\mathrm{Pb}(\mathrm{II})$ from $\mathrm{Cu}$ (II) was carried out at appropriate condition. $\mathrm{Pb}$ (II) was eluted by 0.05 $\mathrm{M}$ tartaric acid at $5.0 \mathrm{pH}$. By changing concentration of tartaric acid (1.0M) at $6.0 \mathrm{pH}, \mathrm{Cu}$ (II) was eluted. The plot of eluted volume versus $\%$ of metal ion elution is shown in Figure 9. No cross contamination was observed for this separation. In separation of $\mathrm{Cd}(\mathrm{II})$ from $\mathrm{Ni}(\mathrm{II})$, $\mathrm{Cd}(\mathrm{II})$ was eluted by $0.05 \mathrm{M}$ tartaric acid at $\mathrm{pH}-5.0$ and then $\mathrm{Ni}$ (II) eluted by $1.0 \mathrm{M}$ tartaric acid at $\mathrm{pH}-6.0$, which shown in Figure 10. The recovery of metal ions has been more than $90 \%$ in all cases. Synthesized resin was very useful for separation of metal ions particularly for heavy metal ions.

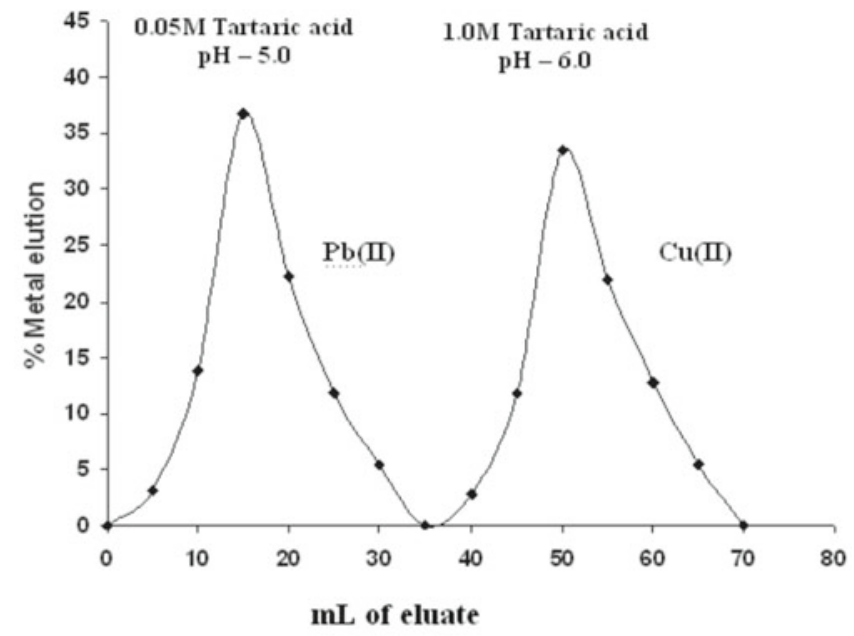

Figure 9. Separation of $\mathrm{Cu}(\mathrm{II})$ and $\mathrm{Pb}(\mathrm{II})$ on $\mathrm{SFO}$ resin

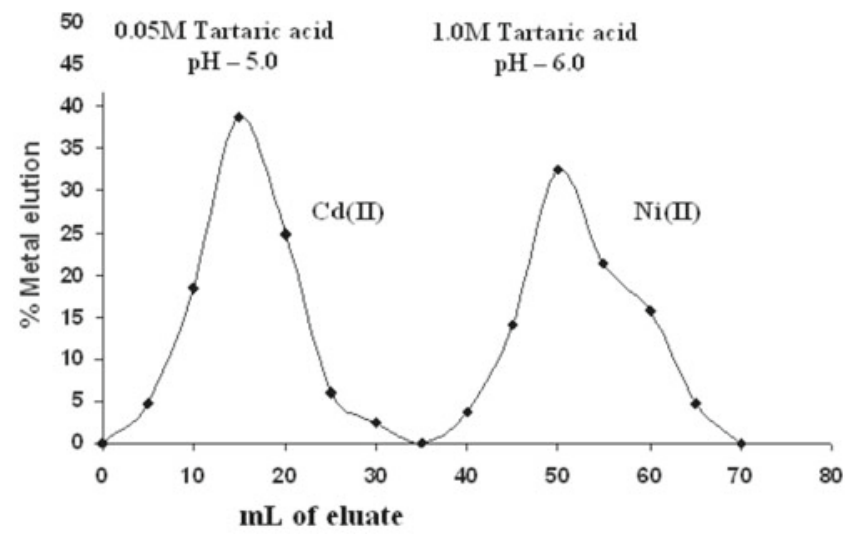

Figure 10. Separation of $\mathrm{Ni}(\mathrm{II})$ and $\mathrm{Cd}(\mathrm{II})$ on $\mathrm{SFO}$ resin

\section{Separation of metal ions from Brass Sample}

The separation of $\mathrm{Cu}(\mathrm{II})$ and $\mathrm{Zn}$ (II) from Brass Sample is carried out in the synthesized resin column. In the separation of $\mathrm{Zn}(\mathrm{II})$ from $\mathrm{Cu}(\mathrm{II})$, the resin column equilibrated at $\mathrm{pH}$ 6.0. $\mathrm{Zn}(\mathrm{II})$ was eluted with $0.5 \mathrm{M}$ tartaric acid. The first few fractions contained only $\mathrm{Zn}$ (II) and the later fractions contained only $\mathrm{Cu}$ (II) which was eluted with 1.0 M tartaric acid at pH 6.0. The plot of the eluted volume versus \% of metal ion elution is shown in Figure 11. No cross contamination was observed for this separation. The recovery of $\mathrm{Zn}$ (II) and $\mathrm{Cu}$ (II) was more than $90 \%$.

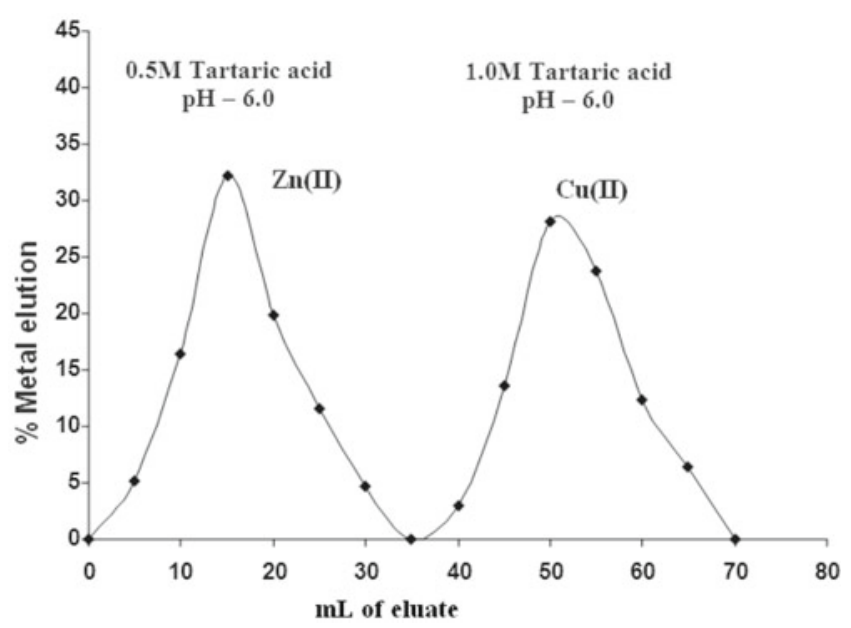

Figure 11. Separation of $\mathrm{Zn}(\mathrm{II})$ and $\mathrm{Cu}(\mathrm{II})$ of Brass Sample on SFO resin

Recovery for Heavy Metal Ions from Purna River Water

To verify the applicability of the present chelating resin using preconcentration of trace metal ions like $\mathrm{Cd}(\mathrm{II})$ and $\mathrm{Pb}(\mathrm{II})$ from river water sample, the extraction and elution of metal ions was studied. The metal ion concentration of $\mathrm{Cd}(\mathrm{II})$ and $\mathrm{Pb}(\mathrm{II})$, in river water and after preconcentration was determined by atomic absorption spectroscopy. The recovery of heavy metal ion from column was carried out using $2 \mathrm{M} \mathrm{HCl} \mathrm{solu-}$ tion. The recovery of $\mathrm{Cd}(\mathrm{II})$ and $\mathrm{Pb}(\mathrm{II})$ ions was $90.47 \%$ and $92.11 \%$. The results indicate that the extraction and elution of $\mathrm{Cd}(\mathrm{II})$ and $\mathrm{Pb}$ (II) is little affected by the coexistence of salt matrices.

\section{CONCLUSIONS}

The synthesized SFO chelating resin exhibits exchange capacities for metal ions which is $\mathrm{pH}$ hdependent. The Highest removal for selected metal ions occurred at 5.0 to $6.0 \mathrm{pH}$. The time required for $50 \%$ exchange $\left(t_{1 / 2}\right)$ was mostly achieved in approximately 30 to $40 \mathrm{~min}$. The exchange capacity of the transition metal ion is greater than that of heavy metal ion because of fewer pores and pits size on the surface of SFO resin. The present investigation shows that cation exchange resin (SFO) can be employed for separation and recovery of metal ion from their mixture. Batch and column methods were done for the separation of heavy metal ion from synthetic binary mixture. The recovery of metal ions from their mixture is about $90 \%$ using suitable eluents. This resin may be also used for wastewater treatment in industries. The use of chelating resin for the separation and removal of metal ions is the method of choice due to its high separation efficiency, good reproducibility of retention parameters and simplicity; therefore, this resin can be used in the enrichment of metal ions from various sources by adopting preconcentration and separation from various matrices. 


\section{LITERATURE CITED}

1. Rao, G.P.C., Rao, M.M., \& Veni, S.S. (2006). Preconcentration of total chromium on Dowex 50WX8 resin loaded with 2-amino-benzenethiol. International Journal of Environmental Analytical Chemistry.86 (14), 1095-1103. DOI:10.1080/03067310600847369.

2. Cheng, C., Jin, N.W., Li, X, \& Ai M.L. (2012). Preparation of new hyper cross-linked chelating resin for adsorption of $\mathrm{Cu}^{2+}$ and $\mathrm{Ni}^{2+}$ from water. Chinese Chemical Letters.23(2), 245-248. DOI:10.1016/j.cclet.2011.10.019.

3. Chandra, D., Kumar, D.S., \& Bhaumik, A. (2010). A fluorophore grafted 2D-hexagonal mesoporous organosilica: excellent ion exchanger for the removal of heavy metal ions from wastewater. Microporous Mesoporous Material.128, 34-40. DOI:10.1016/j.micromeso.2009.07. 024.

4. Park, I.H., \& Kim, K.M. (2005). Preparation of chelating resins containing a pair of neighboring carboxylic acid groups and the adsorption characteristics for heavy metal ions. Separation Science and Technology. 40, 2963-2986. DOI:10.1080/01496390500338060.

5. Gurnule, W.B., \& Patel, D.B. (2011). Metal ion binding properties of a copolymer resin: synthesis, characterization, and its applications. Polymer bulletin. 66, 803-820. DOI 10.1007 / s00289-010-0385-8.

6. Singh, D.K., \& Srivastava, M. (2006). Synthesis Characteristic and Analytical Applications of New chelating resin containing p-Bromophenylhydromaxic acid. Journal of Liquid Chromatography \& Related Technologies. 29(10), 1433-1440. DOI: $10.1080 / 10826070600674828$.

7. Mohan, S., \& Sreelakshmi, G. (2008). Fixed bed column study for heavy metal removal using phosphate treated rice husk. Journal of Hazardous Material. 153, 75-82. DOI: 10.1016/j. jhazmat.2007.08.021.

8. Dogan, C.E. \& Akcin, G. (2007). Solid phase extraction and determination of lead in water sample using silica gel homogeneously modified by thiosalicylic acid. Analytical Letter. 40(13), 2524-2543. DOI: 10.1080/00032710701585016.

9. Helfferich, F (1962). Ion Exchange Resin. McGraw Hills, New York.

10. Kunin, R. (1958). Ion Exchange Resin. (2 $2^{\text {nd }}$ edition) Wiley London.

11. Vogel, S. (2009). Textbook of Qualitative Chemical Analysis. $6^{\text {th }}$ edition Cambridge University Press, Cambridge.

12. Shah, B.A., Shah, A.V., \& Shah, P.M. (2008). Metal ions uptake by chelating resin derived from o-substituted benzoic acid and its synthesis, characterization and properties. Macromolecular Symposia. 274, 81-90. DOI: 10.1002/masy.200851412.

13. Sun, C., Qu, R., Ji, C., Wang, Q., Sun, Y., \& Cheng, G. (2006). A chelating resin containing S, N and O atoms: Synthesis and adsorption properties for $\mathrm{Hg}(\mathrm{II})$. European Polymer Journal. 42(1), 188-194. DOI: 10.1016/j.eurpolymj.2005.06.024.

14. Samal, S., Acharya, S., Dey, R.K., \& Ray, A.R. (2003). Synthesis, characterization and metal ion uptake studies of chelating resin derived from formaldehyde / furfuraldehyde condensed phenolic schiff base of 4, 4'-diaminophenylmethane and o-hydroxyacetophenone. Journal of Applied Polymer Science.88 (2), 570-581. DOI: 10.1002/app.11715.

15. Shah, B.A., Shah, A.V., \& Patel, N.B. (2008). A benign approach of microwave assisted synthesis of copolymer with improved thermal, spectral and ion exchange properties. Iranian Polymer Journal.17 (1), 3-17. http://journal.ippi.ac.ir/journals. php?tab $=1 \& \mathrm{v}=17 \& \mathrm{n}=1$.

16. Shah, B.A., Shah, A.V., \& Shah, P.M. (2010). Selective sorption of heavy metal ions from aqueous solutions using $\mathrm{m}$-cresol based chelating resin and its analytical applications. Iranian Journal of Chemistry and Chemical Engineering 29(2), 49-58. http:// www. sid.ir/en/ VEWSSID /J_ pdf/84320105407. pdf.
17. Bhatt, R.R., \& Shah, B.A. (2007). Studies of Chelation Ion-exchange Properties of Copolymer Resin Derived from Salicylic Acid and its Analytical Applications Iranian polymer journal.16 (3), 173-184. http://journal.ippi.ac.ir/journals.php?ta$\mathrm{b}=1 \& \mathrm{v}=16 \& \mathrm{n}=3$.

18. Rivas, B.R., Peric, I.M., \& Villegas, S. (2010). Synthesis and metal ion uptake properties of water-insoluble functional copolymers: removal of metal ions with environmental impact. Polymer Bulletin.65 (9), 917-928. DOI: 10.1007/s00289-0100304-z.

19. Demirbas, A., Pehivan, E., Gode, F., Altun, T., \& Arslan, G. (2005). Adsorption of $\mathrm{Cu}(\mathrm{II}), \mathrm{Zn}(\mathrm{II}), \mathrm{Ni}(\mathrm{II}), \mathrm{Pb}(\mathrm{II})$ and $\mathrm{Cd}(\mathrm{II})$ from aqueous solution on Amberlite IR-120 synthetic resin. Journal of Colloid and Interface Science. 282:20-25. DOI: 10.1016/j.jcis.2004.08.147.

20. Bajpal, A.K., \& Rai, L. (2010). Removal of chromium ion from aqueous solution by biosorption on to ternary biopolymer microspheres. Indian Journal of Chemical Technology. 17:17-27. http://nopr.niscair.res.in/bitstream/123456789/7271/1/ IJCT\%2017\%281\%29\%2017-27.pdf. 